\title{
Poverty Alleviation Programme and Poverty Reduction in Anambra State. Evidence from Women Business Ownership
}

\author{
Joan N. Ozoh \\ Department of Economics, \\ Nnamdi Azikiwe University, Awka \\ Amaka G. Metu \\ Department of Economics, \\ Nnamdi Azikiwe University, Awka \\ Chukwuka Stephen M. \\ Department of Economics, \\ Nnamdi Azikiwe University, Awka \\ Chinwe Madueke \\ Department of Economics, \\ Nnamdi Azikiwe University, Awka
}

\begin{abstract}
The fight against poverty is one of the key components of the development of any country. If the percentage of poor people is high, there will be slow development. The government policies and program such as YOUWIN, Better Life is aimed at encouraging entrepreneurship and supporting women into business. Despite these efforts, poverty incidence still increases among women in micro business. This study examined government alleviation programs and dimension of poverty among women into micro business in Anambra state, Nigeria. It is a descriptive survey research. Probability and non- probability sampling technique were employed in which the samples were drawn using multi-stage sampling and purposive sampling technique. Questionnaire was used as an instrument for data collection. Data were analyzed using descriptive statistics, chi-square and Multidimensional Poverty Index (MPI). The findings of this study showed that most women participating in micro business are not aware of poverty reduction programs and do not have access to such programs. The study also found out that most of the women still experience hardship, no access to infrastructure, no good health care system and low standard of living which indicates that poverty has not reduced. The study recommended among others that the government should target its reduction policies towards the multidimensional indicators (good infrastructure, good health care system etc.) of poverty in order to eradicate poverty.
\end{abstract}

Keywords-Government policies, Poverty reduction, Micro business Jel classification code: L88, 132, L26

\section{INTRODUCTION}

The world economy is characterized by various problems which the most disturbing one is how to alleviate extreme poverty (Kazeem, 2018). The rising profile of poverty is very alarming and worrisome. Seven hundred and thirty-six million people live in extreme poverty, surviving on less than $\$ 1.90$ a day (Dauda,2016). About 1.75 billion persons suffer from multidimensional poverty, with deprivations in education, economic opportunities, health, and living standard (Dauda,2016). Poverty deprives people of their right to socio-economic well- 
being (Sachs,2005). In Nigeria,86.9 million people live in extreme poverty which represents $50 \%$ of the estimated 180 million population and having a large population of people in poverty with the population boom is a major problem in African countries today (Kazeem, 2018). Poverty is a state of absolute economic deprivation in which the individual cannot independently have access to the basic human life-sustaining essentials such as food, clothing, protection, and shelter (Ali, 2010). Poverty is the lack of income or shortage of assets; the lack of competence, confidence, disempowerment, among others.

Poverty is the main cause of hunger and malnutrition which are aggravated by rapid population growth, inadequate and inconsistent policies (Sanni,2000). Nigeria's population according to Nigeria world facts and focus (2008), based on 2006 last population census was $140,020,250$. In 2012, it was projected at 166.2 million by the National Bureau of Statistics. In 2015, Nigeria's population was projected at 183 million people. In 2019, the population was estimated at 200.96 million which ranks Nigeria the 7 th in the world as the most populated country. (World population review,2019). As the population increases and there is no increase in production and social welfare, poverty rate in Nigeria also increases. The percentage of Nigerians living in absolute poverty, those who can afford only the bare essentials of food, shelter and clothing is about 112.5 million (Kazeem,2018).

Over the years, the Federal government has undertaken some programs with the objective of reducing and totally eradicating poverty in Nigeria. These programs were at least expected to raise the standard of those living in Nigeria. They are means through which the government aims to reconstruct the economy. Some of these programs include Family Support Program (FSP), Community and Small Scale Industries Credit Scheme, the Green Revolution, National Agricultural Land Development Agency(NALDA), Rural Employment Program(REP), National Directorate of Employment(NDE), Poverty Alleviation Program, Seven Point Agenda, National Poverty Eradication Program(NAPEP), Universal Primary Education(UPE), Operation Feed the Nation(OFN), National Directorate for Food, Road and Rural Infrastructure(DFRI), Better LIFE Program (BLP), YOUWIN program, Conditional Cash Transfer(CCT), Homegrown School Feeding, N-Power program, Trader-Moni program etc. Despite these efforts, in 2015, the population in poverty rose to $70 \%$ which also increased to $72 \%$ in 2016 . In June 2018, Nigeria was named the poverty capital of the world by world poverty clock. The number of people living in poverty is about 112.5 million (kazeem, 2018). The high incidence of poverty in the country has made poverty alleviation programs important policy options over the years.

Okuneye (2001) is of the view that the social dimension of poverty is largely a gender issue, Since the greatest weight of poverty is borne by women. Women constitute over half of the economically active population of Nigeria. Together with men, they share the responsibility of sustaining their families through participation in all aspects of labor. In Anambra state, women are known to be hardworking, creative and into micro business ventures such as fashion design, tie and dye, cyber cafe, business Centre, restaurants, fish and meat mongers, GSM recharge card/service, petty trading, local snacks, hair dressing/barbing salon, local juice and akara (bean cake) production etc. which generates income to them (Osunde, 2014).

Micro business help in poverty reduction through generation of employment. With wider ownership spread of micro business, the women get an opportunity to diversify their source of income, create new sources of economic growth and generate additional employment. 20\% of the labor force is employed in micro business in Nigeria (Osunde, 2014). With the growth rate of micro business and also the participation of women in micro business can contribute to enabling households to cope with income shocks to ensure food security, reduce poverty and prevent vulnerable households from falling below poverty line and improve standard of living 
for the people (Hussain, Bhuiyan and Bakar, 2014). When families move out of poverty, children's health and well- being will improve. According to a 2018 survey by the UN Development Program, many families live in multidimensional poverty. They don't have access to good water, sanitation, electricity, shelter, Education etc. Why is the poverty rate increasing despite a huge poverty alleviation program by different administration in Nigeria? There is scarcity of the research in Anambra state. Most of the researchers used income approach as a dimension of poverty but this study will remedy the knowledge gap by looking at other dimensions of poverty to know why poverty is still in existence despite huge poverty reduction strategies.

Hence, this study empirically examined government intervention policy, to find out if women into micro business have access to these programme and to know the dimension of poverty among women into micro business in Anambra state.

Having introduced this study in section 1, section 2 examined government intervention programme, Section 3 review of literature, section 4 research methods and procedure, section 5 result presentation and discussion of findings and section 6 is on summary conclusion and recommendation

\section{GOVERNMENT POVERTY ALLEVIATION PROGRAMME IN NIGERIA}

The fight against poverty is one of the key components of the development of any country. In Nigeria, successive government have over the years put in place policies and measures to address the issue of poverty in the country. As at 1960 to1979, poverty was identified by the Federal government as the scourge of rural development in the country. In order to tackle this, the government embarked on the implementation of River basin Development Authorities (RBDA) , Agricultural Development Project (ADP), Operation Feed the Nation(OFN), Free and Compulsory Primary Education (FCPE), Green Revolution (GR), Agricultural Credit Guarantee Scheme Funds (ACGSF), Rural Electrification Scheme (RES), Rural Banking Programme (RBP), River Basin Development Authority (RBDA). Although some success was made by these programme by enhancing the quality of life of many Nigerians, most of them couldn't be sustained due to lack of political will and insufficient involvement of the beneficiaries.

In 1980, there was an economic crisis caused by external shocks which worsened the quality of life of many Nigerians. IN 1986-2009, to reverse the condition, the Structural Adjustment Programme (SAP),Directorate for Food, Roads and Rural Infrastructure (DFRRI), The National Directorate of Employment(NDE), Mass Mobilization for Social Justice and Economic Reconstruction (MAMSER), Better Life for Rural Women(BLRW), Peoples Bank, Community Bank, Rural Health Scheme (RHS), Expanded Programme on Immunization (EPI), Science and Technology Fund (STF), Natural Economic Recovery Fund (NERF), Family Support Programme(FSP), Family Economic Advancement Programme(FEAP), Poverty Alleviation Programme(PAP), National Poverty Eradication Program (NAPEP), Youth Empowerment Scheme (YES), Rural Infrastructure and Development Scheme (RIDS), Mandatory Attachment Programme (MAP), Capacity Acquisition Programme (CAP), Social Welfare Service Scheme (SOWESS) and Natural Resources Development and Conservation Scheme (NRDCS), National Economic Empowerment and Development Strategy (NEEDS), Seven Point Agenda ,Nigerian Vision 2020.

In 2015 to 2018, School Feeding, Youth and Small-scale Business Guarantee Loan Scheme, government enterprise empowerment programme (GEEP), the N-Power, Upward Review of Salaries and Wages etc. 
However, the programs were beset by a lot of contradictions and distortions that restrained its full implementation. There was lack of standard for project harmonization and effective coordination among the three tiers of government (Taiwo and Agwu,2016). Subsequent administration came with different ideas and this makes the programme to be ineffective. On the other hand, those people who are appointed as heads of programme are only seek for their own pocket and forget the beneficiaries. Again, some of these policies were not sustained because of the problem of corruption, underfunding, political instability and diversion of the programme from its original focus. Those who are supposed to benefit from the programme were not involved because there was no effective monitoring and implementation.

\section{Conceptual Literature Review}

\section{REVIEW OF LITERATURE}

Micro Business- Micro enterprise may be considered as small business if the business runs on an extremely small scale. Small and Median Enterprises Development Agency of Nigeria (SMEDAN,2012), defined micro business as any enterprise employing between one to nine people and having capital base from one naira to five million excluding cost of land. National council on industry (NCI) defined Micro business as an enterprise with total capital which exceeds cost of land not more than 1.5 million naira with labor size of not more than 10 employees. This include cottage industries which are mostly single-family operated business with no employees other than them the owners.

Poverty/Poverty Alleviation- Odion (2009), defined poverty as a deadly socio-economic phenomenon that manifests in a peoples' inability to acquire the basic necessities of life such as (food, clothing and shelter) needed for decent living. According to UNDP report (2018), Poverty is not merely the impoverished state in which a person actually lives in, but a lack of real opportunities due to social and other constraints and circumstances that inhibit living a valuable and dignified life. The concept of poverty goes beyond absence of or low income to include health and nutrition; low education and skills; inadequate livelihoods; poor housing conditions; lack of jobs and social exclusion. According to Adofu and Ocheja (2013), Poverty alleviation refers to sustained improvements in the living conditions of a particular group of people. They posit that poverty alleviation as a concept is closely related to development, which they described as chance process characterized by increased productivity, equalization in the distribution of social products and emergence of indigenous institutions whose relations with the outside world are characterized by equity rather than by dependence or subordination. The aim of any poverty alleviation of any government is to achieve lasting improvements in the quality of life and not just short-term improvement that disappear at the end of the project cycle. Poverty alleviation is therefore aimed at maintaining the natural resource base through a process that adapts properly to the natural environment by making appropriate improvement in the social values of the people, (Paul, 2007).

\section{Theoretical literature}

\section{Sustainable Livelihood Approach}

According to Krantz (2001), The sustainable livelihoods idea was first introduced by the Brundtland Commission on Environment and Development as a way of linking socioeconomic and ecological considerations in a cohesive, policy relevant structure. It was expanded in 1992 by United Nations Conference on Environment and Development. A livelihood comprises the capabilities, assets (including both material and social resources) and activities required for a means of living. Sustainable livelihood is assumed to be an integrating factor that allows policies to address development and poverty reduction simultaneously. The livelihood resources are the natural capital, the economic/financial capital, human capital and social capital. A livelihood is sustainable when it can cope with and recover from stress and shocks, 
maintain or enhance its capabilities and assets, and provide sustainable livelihood opportunities for the next generation; and which contributes net benefits to other livelihoods at the local and global levels and in the short and long term. Chambers and Conway (1992) states that sustainable development requires increasing capacity of rural people to influence and control their future on a long-term basis, a goal that can be achieved by strengthening capacity, supporting equity and fostering empowerment. Sen (1987) refers to capabilities as a concept that is far beyond having more than material things and food but what people can do or acquire with their income. Therefore, it is assumed that Poverty reduction is the major evaluation of livelihood indicating that when capability is guaranteed, the level of poverty will be reduced in the society. The most valuable means to empower people is to broaden the range of strategy alternatives through diversification into livelihood options that actually minimizes vulnerability (Goldman 2000, as cited in Olusola and Oluwasola 2016). Sustainable livelihood approach provides an accurate plan and channels to assess the direct and indirect effects on people's living conditions than one dimensional productivity or income criteria. This theory offers the prospects of a more coherent and integrated approach to poverty.

\section{Empirical literature review}

A number of Studies provided empirical evidence on the role of women micro business on poverty alleviation in Nigeria. Such studies revealed that women micro business has played a significant role in poverty alleviation. For instance, Ajala and Fakoya (2003) using frequency tables, percentages and chi-square, examined the role of women small scale business activities on poverty reduction in Oyo state using structured questionnaires to generate primary data from 180 small scale women entrepreneurs and found a positive relationship between micro business and poverty reduction. Audu and Okpe (2018) assessed women in small scale enterprises and poverty in Kogi state using interviews and questionnaires to elicit information from the respondents found a significant positive impact on poverty reduction. Jonathan, Victor and Tuluma (2013) examined small scale enterprise, poverty alleviation and job creation using burnt brick layers in Benue state found that burnt bricklaying has significant positive impact on poverty alleviation, job creation, and income generation in Nigeria. Adebayo and Lanrewaju (2014) using Counterfactual or Difference-in-Difference model of impact assessment examined the impact of micro and small business on poverty reduction in Ibadan found a strong positive impact on poverty reduction. Umogbai, Diaka and Ekeh (2016) using well-structured questionnaire studied small scale industries and poverty reduction in Benue state and found a positive relationship between small scale enterprises (SMEs) and poverty alleviation. Osemene, Salman, and Kolawole (2017) using an income approach examined how SMEs contribute to poverty alleviation revealed that income generated by owners of SMEs impacts strongly on poverty alleviation. Agupusi (2007) in its critical analysis on the role of small business development and poverty reduction in Alexandra found a positive impact of micro business on poverty reduction. Ajay (2007) using inferential analysis examined micro enterprises and household income, observed a positive impact of micro business on poverty reduction. Misango, and Ongiti (2013) examined whether women entrepreneur play a role in reducing poverty in Kenya found a positive impact of women micro enterprises on poverty reduction. Samwel (2014) using regression examined the role of women's' micro enterprises in enhancing rural household access to basic needs and services in Tanzania specifically on women selling fish and found a significant positive impact on poverty reduction. Olusola and Oluwasola (2014) examined the impact of small business on poverty reduction in South Africa found a positive impact on poverty alleviation. Some studies found a negative impact of micro business on poverty reduction such as Ali and Khan (2014) using OLS method examined the role of small and medium enterprises on poverty in Pakistan found a strong and negative impact of micro business on poverty reduction in the area. In their study, they used variables 
like consumer price index, health expenditure, population growth rate and poverty head count ratio to measure poverty.

On the other hand, some studies advocated that some Policies like micro credit scheme are not well distributed and therefore does not get to the hand of the recipient. For instance, Agbionu, Agbionu, Ikon, Chinwe, (2015) using a survey research in Awka found that despite the provision of loans by the government, women entrepreneur in Awka still complain of lack of financial assistance from government and their study concluded that the micro credit provided by the government does not get to the hand of women into micro business in Awka.

If micro business helps in the reduction of poverty, why is there still in existence poverty in the country? There is Scarcity of the research in Anambra State. Most of these studies looked at poverty from the income approach. They did not try to look at it from the multi- dimensional approach. This study will remedy the knowledge gap by looking at the multidimensional approach to see if women in micro business has reduced poverty in Anambra state.

\section{SAMPLING AND SAMPLING TECHNIQUE}

This study used a descriptive survey research design. Questionnaire was used as an instrument for data collection. The location of this study is Anambra state and the population of this study is women participating in micro business in Anambra state. The sampling unit for this study is the individual (women) who are involved in micro business. The researcher made use of multistage sampling technique. The researcher stratified 21 local governments in Anambra state into three senatorial district namely-Anambra North, Anambra Central and Anambra South. In the First stage, the researcher selected one local government from each stratum which are Dunukofia, Ayamelum and Aguata. In the second stage, the researcher randomly selects 3towns from each L.G.A which are Umunnachi, Ifitedunu, Ukpo, Omor, Ifite Ogwari, Anaku, Ekwulobia, Akpo and Achina and in the third stage, the researcher Purposively selects women into micro business. Using Kothari Formula, the population of women into micro business was 699,395 which amounts to 384 sample size. The sample size for this study was adjusted to 400 to have a good representation of the population.

\section{ESTIMATION AND DATA PRESENTATION}

A multidimensional poverty (MPI) index of Alkire and Foster (2007, 2011a \& b) and Alkire, Roche, Santos and Seth (2011) is used to compute the poverty index of women in micro businesses in Anambra. Our MPI consists of three dimensions and ten indicators. Each woman in our sample is assigned a deprivation score according to her deprivations in the component indicators. The deprivation score of each person is calculated by taking a weighted sum of the deprivations experienced. The score increases as the number of deprivations of the person increases and reaches its maximum when the person is deprived in all ten indicators. A person, who is not deprived in any indicator, receives a score equal to 0 . For instance, an individual who is deprived in the two indicators of health will have a score of 3.34 and 0 if not deprived. The individual is considered to be multidimensional poor if her total sum of deprivation score is greater than or equal to 3 . 


\section{Descriptive Statistics}

Table 5.1: Characteristics of the operators

\begin{tabular}{|c|c|c|c|}
\hline Variable & Category & Frequency & Percentage \\
\hline \multirow[t]{3}{*}{ Age } & 15 years -35 years & 196 & $51.4 \%$ \\
\hline & 36 years - 56 years & 133 & $34.6 \%$ \\
\hline & 56 years and above & 55 & $14 \%$ \\
\hline \multirow[t]{5}{*}{ Marital Status } & Single & 103 & $26.8 \%$ \\
\hline & Married & 242 & $63 \%$ \\
\hline & Divorced & 8 & $2.1 \%$ \\
\hline & Separated & 8 & $2.1 \%$ \\
\hline & Widowed & 23 & $6 \%$ \\
\hline Educational & Primary & 76 & $19.8 \%$ \\
\hline \multirow[t]{3}{*}{ Qualification } & Secondary & 237 & $61.7 \%$ \\
\hline & Tertiary & 55 & $14.3 \%$ \\
\hline & None & 16 & $4.2 \%$ \\
\hline \multirow[t]{5}{*}{ Type of Business } & Salon & 100 & $26 \%$ \\
\hline & Petty trading & 172 & $44.8 \%$ \\
\hline & Fashion \&designing & 40 & $10.4 \%$ \\
\hline & Recharge card services & 16 & $4.2 \%$ \\
\hline & Agro business & 56 & $14.6 \%$ \\
\hline \multirow[t]{2}{*}{ Business Ownership } & Sole proprietorship & 376 & $97.9 \%$ \\
\hline & Partnership & 8 & $2.1 \%$ \\
\hline \multirow[t]{4}{*}{ Source of Capital } & Personal savings & 173 & $45 . \%$ \\
\hline & Relative \& friends & 195 & $50.8 \%$ \\
\hline & Government & Nil & $0 \%$ \\
\hline & Bank/micro finance & 16 & $4.2 \%$ \\
\hline
\end{tabular}

Source: The Researcher based on Field Survey, (2019)

Table 5.1 shows the characteristics of women in micro business in rural area in Anambra state, using frequency and percentage tables. The study shows that 196 women in micro businesses in rural area in Anambra state within the age bracket of 15 - 35 years. This number represents about $51.4 \%$ of the sampled population. While 133 of them, representing $34.6 \%$ fall within the age bracket of 36 - 56 years, 55 of the rural women in micro businesses are 55 years and above. This figure represents $14 \%$ of the total women studied. Obviously, a good number of young women in the rural area are engaged in micro businesses. The number of single women who engage in micro business in the rural area is 103 , representing $26.8 \%$ of the total number sampled. Married women constitute $63 \%$ of the total sample while those who are either divorced or separated represent $2.1 \%$ of the sample apiece. However, $6 \%$ of the women in micro business claimed they are widowed. Again, single and married women represent a good number of micro business operators in rural area in Anambra state. On educational qualification, majority of the participants attained secondary school education.237 women, representing $61.7 \%$ of the total women studied schooled up to secondary school level. While 76 and 55 women, representing 19.8\% and 14.3\% completed primary and tertiary education respectively, 16 of them do not have any formal qualification. The Table above further revealed that most of the women in micro business in rural area engage in petty trading and salon services, about $44.8 \%$ and $26 \%$ respectively. This numbers are followed by agro business, fashion and designing. These present $14.6 \%$ and $10.4 \%$ of the total participants respectively. Majority of these micro businesses are sole proprietorship and they sourced their capital via personal savings or from relatives and friends. Just about $4.2 \%$ of the rural women in micro businesses got loan from bank/micro finance. The study also revealed that none of the participants was able to source or get fund from the government. This is surprising given the 
Ozoh, J. N., Metu, A. G., Stephen, C. M., \& Madueke, C. (2020). Poverty Alleviation Programme and Poverty Reduction in Anambra State. Evidence from Women Business Ownership. Advances in Social Sciences Research Journal, 7(1) 217-229.

Federal Government's TraderMoni empowerment scheme that targets those in micro businesses across the country.

Table 5.2: Programme Awareness * Programme Accessibility Cross tabulation

Count

\begin{tabular}{lcccc}
\multicolumn{1}{c}{} & \multicolumn{2}{c}{ Accessibility } & Total \\
& & Yes & No & 79 \\
Awareness & Yes & 23 & 56 & 305 \\
Total & No & 0 & 305 & 384 \\
\hline
\end{tabular}

Source: The Researcher based on Field Survey, (2019)

Table 5.2 shows that a total of 79 rural women in micro businesses in Anambra State are aware of government poverty reduction programme, this number represents just $20.6 \%$ of the total number of sampled women in micro businesses in rural area. Out of these 79 women, only 23 of them have access to government's poverty reduction programme. This result implies that only $29 \%$ of the women who are aware of the said government's poverty reduction programme are able to access the programme. The remaining $71 \%$, though aware of the programmes, are not able to access them. On the other hand, 305 of the rural women in micro business are not aware of any existing government poverty reduction programme, while 361 of them do not have access to the said programme. These numbers represent $79.4 \%$ for nonawareness and $94 \%$ for non-accessibility.

To test the null hypothesis that women in micro business have access to poverty reduction programs in Anambra state, we use Chi-Square. Chi-Square is used to test for association or independence of the opinions of the respondents on access to poverty programme or not. The result is presented on Table 4.3.

Table 5.3: Access to government's poverty reduction programme

\begin{tabular}{|l|c|c|c|}
\hline & Observed N & Expected N & Residual \\
\hline Yes & 23 & 192.0 & -169.0 \\
No & 361 & 192.0 & 169.0 \\
Total & 384 & & \\
\hline
\end{tabular}

\begin{tabular}{|l|l|}
\hline & Access \\
\hline Chi square & 2.975 \\
df & 1 \\
Assymp. P. value & .000 \\
\hline
\end{tabular}

a. 0 cells $(.0 \%)$ have expected frequencies less than 5 . The minimum expected cell frequency is 192.0.

\section{Source: The Researcher Field Survey, (2019)}

Under the null hypothesis that women in micro business have access to poverty reduction programs in Anambra state, we reject the null if the $p$-value (labeled Asymp. Sig.) is less than 0.05. The results revealed that the null hypothesis cannot be accepted. Thus, we reject the null hypothesis and conclude that women in micro business have no access to poverty reduction programs in Anambra state. 
We also constructed a multidimensional poverty index (MPI) for women in micro businesses and then related it (the MPI) to women participation in micro business. These questions covered three dimensions of poverty in ten indicators, namely: health with nutrition and child mortality as indicators, education with years of schooling and school attendance as indicators and living standard with cooking fuel, sanitation, water, electricity, floor and asset as indicators. Each indicator is multiplied by its theoretical weight, the theoretical weight for health and education is 1.67, while that of living standard is 0.58 (Alkire \& Foster, 2007, 2011a \& 2011b, Alkire, Roche, Santos \& Seth, 2011). The result is summed up to obtain the Score ci (sum of each deprivation multiplied by its weight). The household is considered poor across dimension if his score $\mathrm{c}$ is greater than or equal to the cut-off given by $1 / 3(=0.3333)$.

\section{Two steps are then followed to calculate the MPI:}

Step 1: Each person is assessed based on household achievements to determine if he/she is below the deprivation cut-off in each indicator. People below the cut-off are considered deprived in that indicator.

Step 2: The deprivation of each person is weighted by the indicator's weight (an explanation on weighting can be found in section 3). If the sum of the weighted deprivations is 33 per cent or more of possible deprivations, the person is considered to be multidimensional poor.

\begin{tabular}{|c|c|c|c|}
\hline \multicolumn{4}{|c|}{ Composition of the MPI - dimensions and indicators } \\
\hline Dimension & Indicator & Deprived if ----- & Weight \\
\hline \multirow[b]{2}{*}{ Health } & Nutrition & ---any adult or child is malnourished & $1 / 6$ \\
\hline & $\begin{array}{l}\text { Child } \\
\text { mortality }\end{array}$ & ---- any child has died in the family & $1 / 6$ \\
\hline \multirow[t]{2}{*}{ Education } & $\begin{array}{l}\text { Years of } \\
\text { schooling }\end{array}$ & $\begin{array}{l}\text {---- no household member has completed five years of } \\
\text { schooling }\end{array}$ & $1 / 6$ \\
\hline & $\begin{array}{l}\text { School } \\
\text { attendance }\end{array}$ & ---- any school-age child is not attending school in years 1 to 8 & $1 / 6$ \\
\hline \multirow{6}{*}{$\begin{array}{l}\text { Living } \\
\text { Standard }\end{array}$} & Cooking fuel & --- the household cooks with wood, charcoal or dung & $1 / 18$ \\
\hline & Sanitation & $\begin{array}{l}\text {---- the household lacks adequate sanitation or if their toilet is } \\
\text { shared }\end{array}$ & $1 / 18$ \\
\hline & Water & $\begin{array}{l}\text {---- the household does not have access to clean drinking } \\
\text { water or clean water is more than } 30 \text { minutes' walk from } \\
\text { home }\end{array}$ & $1 / 18$ \\
\hline & Electricity & --- the household has no electricity & $1 / 18$ \\
\hline & Floor & ---- the household has a dirt, sand or dung floor & $1 / 18$ \\
\hline & Asset & $\begin{array}{l}\text {--- the household does not own more than one of: radio, TV, } \\
\text { telephone, bicycle, motorcycle, refrigerator }\end{array}$ & $1 / 18$ \\
\hline
\end{tabular}


The result is shown below.

Figure 5.1: MPI among rural women in micro business in Anambra state

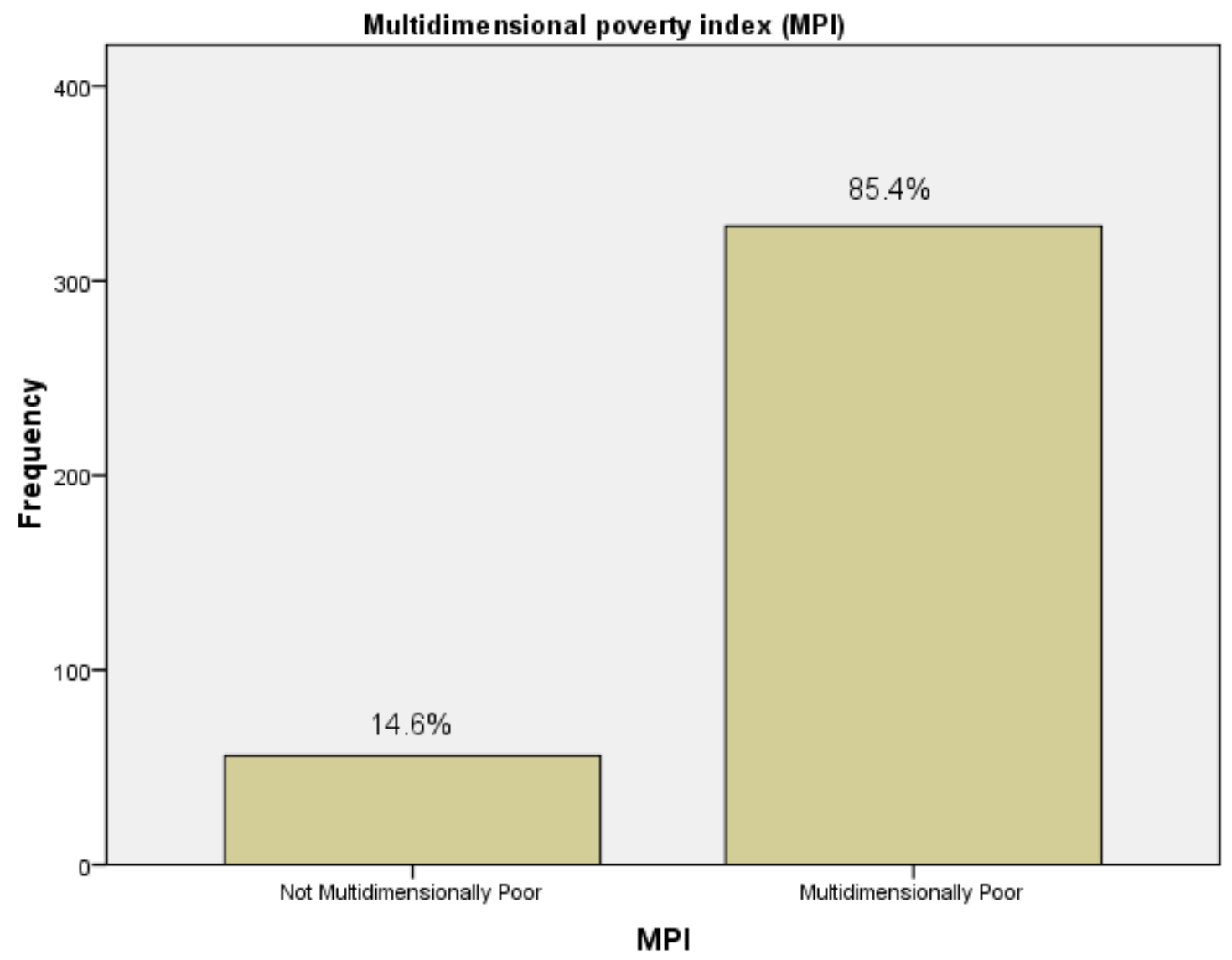

Source: Researcher Field Survey, (2019)

The result shows that out of the 384 rural women in micro businesses sampled, 56 of them representing $14.6 \%$ of the total number are not poor across dimension, while 328 of them, which represent $85.4 \%$, are poor across dimension. Relating this to the number of women participating in micro businesses in rural area suggests that the null hypothesis that women participations in micro business have reduced poverty is rejected, hence we conclude that women participations in micro businesses in rural area have not reduced poverty in Anambra state.

\section{SUMMARY AND RECOMMENDATION}

Poverty is a common feature in our rural society today. $65 \%$ of Nigerians live below the poverty line without access to basic goods and services. The study found that women into micro business have no access to the programmes and are Multidimensional poor in which they still experience hardship, malnutrition, no access to infrastructures, good health care system and low standard of living therefore, poverty has not reduced among women into micro business in Anambra state. The study also found that most of the poverty alleviation programmes are not geared towards the targeted people and it lacks continuity as different idea comes from subsequent administration. Hence the following recommendations:

The government or the agencies should create awareness for all the empowerment programmes which can come in the form of organizing seminars for the women. From these seminars, the women will be able to know and have access to the empowerment programmes geared towards reduction of poverty among micro business owners. 
$>$ Government should also target policies on multidimensional (such as standard of living, health, education) indicators of poverty. This will help policy makers to see where challenges lie and what needs to be addressed in order to eradicate poverty among microbusiness women.

$>$ Government should try as much as possible to continue with the previous policy instead of making new ones so that the policy can be productive and also put up effective monitoring and implementation.

\section{References}

Adebayo, N.A., \& Lanrewaju, N. M. (2014). Impact of micro and small business entrepreneurship on poverty reduction in Ibadan Metropolis, South Western Nigeria. International Review of Management and Business Research,3(3),1603-1626.

Adofu, I., \& Ocheja, A. (2013), Alleviating Poverty Through the use of Entrepreneurship Skill Acquisition in Kogi State, Nigeria. International Open Journal of Economics, 1(2), 14-23

Agbionu, E.O., Agbionu, C.U., Ikon ,M.A., Chinwe, O.V. (2015). Women entrepreneurship and poverty alleviation in Awka metropolis. Journal of Entrepreneurship and management, 4(4),1-9

Agupusi, P. (2007). Small business development and poverty alleviation in Alexandra, South Africa. Paper prepared for the second meeting of the society for the study of economic inequality (pp 12-14). Ecineq society, Berlin.

Ajala, C. G., \& Fakoya, E. O. (2003). Women's small scale business activities towards poverty alleviation in Ibadan North-East Local Government area of Oyo State. Asset Series. 3(1),1-6.

Ajay, T. (2007). Micro enterprises and household income. Journal of Nepalese Business Studies.4(1).

Ali, S. (2010). The small and medium enterprises and poverty reduction in Pakistan: An empirical analysis. European Journal of Business and Economics, 8(2), 25-30.

Ali, S. R. H., \& Khan, M. A. (2014). The role of small and medium enterprises and poverty in Pakistan: An empirical analysis. Theoretical and Applied Economic and Business Research, 21(14), 67-80.

Alkire, S., \& Foster, J. E. (2007). Counting and multidimensional poverty measures, WorkingPaper 7, Oxford Poverty and Human Development Initiative, University of Oxford.

Alkire, S., \& Foster, J. E. (2011a). Counting and multidimensional poverty measurement, Journal of Public Economics, 95, 476-487.

Alkire, S., \& Foster, J. E. (2011b). Understandings and misunderstandings of multidimensional poverty measurement. Journal of Economic Inequality, 9(2), 289-314.

Alkire, S. J. M., Roche, M. E., Santos, P., \& Seth, S. (2011). Multidimensional poverty index 2011: Brief methodological note. OPHI Working Paper, www.ophi.org.uk

Asika, N. M. (1991). Research methodology in social science. Lagos: Estorise Publisher Nigeria Limited

Audu, H.O., \& Okpe, I.J. (2018). Women in small scale enterprises and poverty reduction in Dekina Local Government area of Kogi state: A logistic regression approach. Journal of Economics and Finance, 9(3), 64-71.

Chambers, R., \& Conway, G. (1992). Sustainable rural livelihood: Practical concepts for the 21st century. IDS Discussion paper 296.IDS, Brighton,Uk.

Dauda, R.S. (2016): Poverty and Economic Growth in Nigeria: Issues and Policies, Journal of Poverty, DOI: $10.1080 / 10875549.2016 .1141383$

Eradicating poverty through evolving micro, small, \& medium enterprises: An empirical exploration. Retrieved October 102018 from https://www.researchgate.net/publication/303279534.

Human Development Report (2006). Beyond scarcity: Power, poverty and the global water crisis. New York: Palgrave Macmillan

Hussain, M. D., Bhuiyan, A. B., \& Bakar, R. (2014). Entrepreneurship development and poverty alleviation: An empirical review. Journal of Asian Scientific Research, 4(10), 558-573.

Ikande, M. (2018). Top most important poverty alleviation programmes in Nigeria.Retrieed from https://www.googleadservices.com

Jhingan, M. L (2007). Advanced economics theory (11th ed.), Vrinder publications (p) Ltd. 
Ozoh, J. N., Metu, A. G., Stephen, C. M., \& Madueke, C. (2020). Poverty Alleviation Programme and Poverty Reduction in Anambra State. Evidence from Women Business Ownership . Advances in Social Sciences Research Journal, 7(1) 217-229.

Jonathan, E.O., Victor A. M., \& Tuluma I. E. (2013). Small scale enterprises, poverty alleviation and job creation in Nigeria: lessons from burnt bricklayers in Benue State. Journal of Economics \& Sustainable Development, 4(18), 115 .

Hussaini M, (2014). Poverty alleviation programme in Nigeria:issues and challenges.International journal of development research 4(3).717-720

Kazeem, Y. (2018). Nigeria has become the poverty capital of the world. Retrieved from https;//qz.com/africa/1313380/nigeria-has-the-highest-rate of extreme-poverty-globally.

Krantz, L. (2001). The sustainable livelihood approach to poverty reduction: An introduction. Swedish international development cooperation agency.

Marger, M. (2008). Social inequality: Patterns and process (4th Ed.). New York: McGraw Hill

Misango, S. B., \& Ongiti, O. K. (2013). Do women entrepreneurs play a role in reducing poverty? A case in Kenya. International Review Management and Business Research.2(1), 87-103.

Muklis, L., Mohammad, D. H., \& Mohdsuberi, A. H. (2017). Micro enterprise development and income sustainability for poverty reduction: A literature investigation. International Journal of Business and Technopreneurship, 7(1),23-36.

Mukras, S. M. (2003). Poverty reduction through the strengthening of small and medium enterprises. Journal of African Studies, 17(2), 58-67.

National Bureau of Statistics (2018). Poverty profile for Nigeria. Retrieved from https//: www.nbs.com $14 / 11 / 2018$

Nurkse, R. (1953). Problem of capital formation in under-developed countries. Oxford: Black Well.

Nwobi, A.U., \& Onwuasoanya, P. H. (2014). Rural women involvement in the eradication of poverty in Anambra State, Nigeria. Journal of Education and Practice, 5(32), 104-110.

Odion, W. E. (2009). Millennium development goals (MDGS) and the poverty questions in Nigeria. In Omotor, D.G, \& Akpotor, A.S. (Eds). Millennium development goals and challenges. Abraka: Delse Investment Nigeria Limited.

Okuneye,P. A.(2001).Rural poverty assessment and control in Africa.An invited specialization course paper presented at the united nations IDEP,DAKAR,Senegal.

Olusola, A., \& Oluwasola O. (2014). The impact of small business in poverty reduction in Eastern Cape Province, South Africa. Meditaranean Journal of Social Sciences.5(15).

Osemene, O. F., Salman, R.T., \& Kolanole, K. D. (2017). Impact of small and medium scale enterprises on poverty alleviation in Kwara State, Nigeria. The Pacific Journal of Science and Technology,18(1), 174-182.

Osunde, C. (2014). Entrepreneurs and entrepreneurship in developing countries: The Nigerian experience. The Standard International Journals on Industrial, Financial and Business Management 2, 26-32.

Ovie F.F. (2011). An appraisal of poverty alleviation programme in Nigeria.JORIND,9,297-299

Sachs, J. (2005). The end of poverty: Economic possibilities of our time. New York, Penguin Audio book

Samwel, P. (2014). The role of women's micro-enterprises in enhancing rural household access to basic needs: Evidence from fish selling micro-entreprises in kilwa District, Tanzania. Journal of Education and Practice,5(32).

Sanni, L. O. (2000). Agricultural development without post-harvest system: Any hope for success?. University of Agriculture Abeokuta Alumni Association lecture series,2,23

Sen, A. K. (1987). Poverty and families: An essay on entitlement and depreciations. Oxford: Claredon Press.

Singer, A. E. (2006). Business strategy and poverty alleviation. Journal of Business Ethics, 66, 225-231.

Subair, R. (2012, February). Nigeria has become the poverty capital of the world. Vanguard News. Retrieved from http://www/vangurdngr,com

SMEDAN, (2012). Survey report on micro, small and medium enterprises (MSMEs)in Nigeria. Retrieved from http://www.smedan.gov.ng

Taiwo, J.N. \& Agwu, M.E. (2016). Problems and prospects of poverty alleviation programme in Nigeria. International Journal of Business and Management Review

Umogbai, M., E., Diaka H., \& Ekeh L. (2016). Small scale industries and poverty reduction in Benue state, Nigeria. Imperial Journal of Interdisciplinary Research 2, (8). 
Vandenberg, P. (2006). Poverty reduction through small enterprises: Emerging consensus, unresolved issues and ILO activities. Journal of Small Enterprise Development. 2(1),20-26

World population review (2019). Nigeria population. Retrieved from https://www.worldpopulationreview.com/countries/orgaans-population 